\title{
Contesting the Dominant Discourse of Child Sexual Abuse: Sexual Subjects, Agency, and Ethics
}

\author{
Teguh Wijaya Mulya ${ }^{1}$ (i)
}

(C) Springer Science+Business Media, LLC, part of Springer Nature 2018

\begin{abstract}
Responding to previous scholars' call to explore the complexities of child sexual abuse (CSA), this article presents narratives of CSA and scrutinizes a binary construction underpinning this discourse of CSA, namely, the positioning of children as powerless and adults as powerful. The narratives belong to three Indonesian young people who have had sexual interactions with adults when they were children. The findings demonstrate how this binary positioning has been both drawn upon and resisted in the ways participants understand their sexual experiences. This article contributes to the existing literature by providing analyses of some vignettes of everyday experiences of how children might be constituted as sexual subjects, including their capability to exercise agency, perform resistance, and negotiate ethics. The implications of the findings are discussed in relation to how the recognition of children as sexual subjects and their sexual agency might be beneficial for parents, educators, and counselors.
\end{abstract}

Keywords Child sexual abuse $\cdot$ Sexual agency $\cdot$ Sexual subjectivity $\cdot$ Discourse $\cdot$ Indonesia

\section{Introduction}

Contemporary discussions on child sexual abuse (CSA) have been characterized by the attention to the predatory nature of male sexuality as the source of abuse, criminalization of the demonized perpetrator, and compassion for the devastated innocent victim. Responding to these characterizations, scholars have called for a

Teguh Wijaya Mulya

teguh@staff.ubaya.ac.id

1 Faculty of Psychology, University of Surabaya, Jalan Raya Tenggilis Mejoyo, Surabaya 60293, Indonesia 
more complex ways to understand CSA in terms of its contexts, experiences, consequences, and underlying logics (Angelides 2004; Kendall-Tackett et al. 1993; Malón 2009; Oellerich 2002). This article joins these scholars in the effort to explore and (re)present complexities in the experience of CSA, with an aim of destabilizing the logic underpinning this discourse of CSA, namely, the binary positioning of children as powerless and adults as powerful. These accounts are analyzed to demonstrate in what ways this binary positioning has enabled/constrained children's sexual agency, and how this binary might be disrupted in their becoming of sexual subjects in an Indonesian context.

The term CSA in this article refers to the World Healh Organisation and the International Society for Prevention of Child Abuse and Neglect's definition (WHO 2006, p. 10): "The involvement of a child in sexual activity that he or she does not fully comprehend, is unable to give informed consent to, or for which the child is not developmentally prepared, or else that violates the laws or social taboos of society." This definition implies that "all sexual acts between an adult and underage child (even with child assent) are, by definition, CSA" (Murray et al. 2014, p. 323). In this definition, CSA may or may not involve violence (e.g., force, coercion, or threat) because the main concern is the age of consent or maturity of the persons involved. Researchers disagreed on the exact age of consent, from 12 years old (Wyatt and Peters 1986), 18 years old (Finkelhor et al. 2014), to the relatively "large age or maturational difference between the partners" (Finkelhor 1999, p. 101). The United Nation Children's Fund's (UNICEF) suggests a consultation to the national law in each country for the age of sexual consent (UNICEF 2010, p. 6). Indonesian Child Protection Law ("Undang-undang" 2014) defines a child as a person below 18 years old. This article analyzes and discusses the discourse of CSA according to this definition and age limit.

In this article I will first provide a brief introduction into the context of the research — that is, Indonesia-vis-à-vis child sexual abuse, including previous studies that have been conducted in this context. I will then elucidate my Foucauldian theoretical approach, before reviewing a number of studies on child sexuality, agency, and ethics - from which this article was built on and sought to contribute. After explaining the methodology of this study, I will examine narratives from three young Indonesians to explore various ways the binary positioning of children as powerless and adults as powerful has been drawn on and resisted in the constitution of these young people's sexual subjectivity.

\section{Brief Introduction to Child Sexual Abuse in Indonesia}

In April 2014 there was a case of (violent) CSA that occupied the headlines of all national newspapers and TV news in Indonesia. It was a report from the parents of a 5-year-old male student in Jakarta International School (JIS)—one of the most expensive international private schools in Indonesia-that their child had been "sodomized" by the cleaner at school (Sari 2014). The parents observed that recently their son often cried, behaved anxiously, and had nightmares. When they asked him he said that in the school's toilet he was touched by an adult: "He puts his 'thing' 
inside my butts so deep. Other times I didn't want to but he said he will hit me. He undressed my clothes. I cried but he said 'Don't cry!'." Not long after that parents of two other students also reported similar stories. Five cleaners and gardeners from Jakarta International School were immediately arrested.

This case ignited strong reactions from various groups in Indonesia. Members of the Parliament immediately proposed a change in the Child Protection Law, particularly around increasing the punishment for the perpetrator and providing more support for survivors (Syahni 2014). Discussions and movements against CSA were then increased such as campaigns and education programs conducted by local governments, universities, and professional associations; and also online petitions against CSA (Liauw 2014). JIS themselves claimed that they have installed more than 400 surveillance cameras in the school building to prevent such incidents from happening again (Rahmawati 2014) — a move which was then followed by many other schools. National Commission for Children Protection then coordinated with the Police Department and the Ministry of Education to support the survivors, monitor this case in the court, and strengthen their on-going child abuse prevention programs.

CSA (and prevention of it) is not new in Indonesian public discourses. The JIS case is just one among many recurring news about CSA in Indonesia. According to National Commission for Child Protection between 2010 and 2014 there were $21,869,797$ cases of child abuse and half of them were sexual abuse (Saleh 2014). In general, child sexual abuse (and sexual assault/violence against women) has gained public attention after the 1998 democratic reform, partly because of the awarenessbuilding efforts by the National Commission on Violence against Women. Due to public demand, this commission was established in October 1998 after the systematic mass rape of hundreds of Chinese Indonesian women during the riots that toppled president Soeharto (Berfield and Loveard 1998; Blackburn 1999). One of the commission's achievements has been the passing of the 2004 Domestic Violence Law which criminalizes various acts of domestic violence, including child sexual abuse by family members. This commission has also established Integrated Service Centre for Women's and Children's Empowerment at the city/town and provincial levels in some parts of Indonesia. Through this commission's advocacy and campaigns, a discourse of CSA previously unfamiliar in Indonesia became more widely circulated.

Although the media and government institutions consistently reported new cases and increasing statistics of CSA in Indonesia, there is a dearth of academic publications in this area. Existing studies on sexual abuse and violence in general in Indonesia have focused mainly on two areas. The first is research on sexual assault in times of crisis and conflict, such as multiple rape cases that occurred during the May 1998 riot (Berfield and Loveard 1998; Marching 2007), after the 2004 tsunami in Aceh (Felten-Biermann 2006), and in conflict areas such as Poso (Perempuan 2009), Aceh (Green 2004), and Papua (Wandita 1998). The second major area of research has focused on sexual violence by intimate partners in marital contexts (e.g., Aisyah and Parker 2014; Bennett et al. 2011; Hayati et al. 2011). Academic publications on sexual abuse and violence in Indonesia beyond these two areas are considerably rare, particularly child sexual abuse. For instance, in Child Abuse and Neglect 
journal there are only two publications from Indonesian contexts, one of them being a short report from over 35 years ago (Boothby and Stark 2011; Haditono 1981). In the Sexuality and Culture journal there is no study investigating data or narrative from Indonesian contexts. I intend, in this article, to begin filling this gap. Simultaneously, I also seek to extend current international knowledge on the discursive aspect of CSA, particularly the possibility to destabilize the logic underlying this discourse of CSA. In the next section, I review relevant international research to show how this article might contribute new knowledge to the existing body of scholarship on CSA.

\section{The Discursive Construction of Children as Powerless/Innocent and Adults as Powerful/Exploitative}

Before reviewing previous studies pertinent to the contribution of this article, I will briefly elucidate the conceptual framework informing my analyses of CSA. Theoretically, the current study is underpinned by a Foucauldian poststructuralist approach to discourse, subjectivity, agency, and resistance. Discourse is understood as a set of connected ideas through which individuals give meaning to their experience (Foucault 1972; Weedon 1987). Discourse is not singular, nor static, but multiple and continuously shifting. In every society, there are always competing discourses which offer different ways to give meaning to one's experience-some are more dominant or appearing as "natural", and some are marginal. A discourse of sexual violence, for example, consists of ideas about how non-consensuality, coercion, or threat may occur in a sexual encounter. This discourse might not always be available to be drawn on in understanding one's experience, such as in traditional marital contexts where the husband is positioned as having the rights to demand sex whenever he wants regardless of the wife's consent. In such situation, non-consensual sex (within marriage) might not be understood as sexual violence. Different from the concept of ideology, discourse constitutes one's knowledge; not manipulating nor concealing "the truth." In this poststructuralist approach, there is no "truth" or "reality" outside of discourse.

Discourse continuously constitutes individual's thoughts and emotions about their sense of self (i.e., subjectivity) by offering various ways of seeing and being, or subject positions, to be taken up (Foucault 1982; Weedon 1987). The discourse of CSA, for example, offers various subject positions such as the perpetrator, victim, survivor, or bystander; with each of these has its own discursive meanings which are both enabling and limiting individual's action in different ways. Individuals are not passive or merely subjected to discourses in the constitution of their subjectivity, but they are agentic subjects who give meaning and make choices by drawing on discourses available in their situations (Davies 1991). This capability of individuals to exercise agency is precisely where the possibility of resistance lies, that is, in drawing on other discourses to give alternative meanings beyond those offered by the dominant discourse (Foucault 1978, 1985). For instance, individuals may resist the positioning of themselves as a victim-which implies a state of helplessness, devastated, and needing external help_-by taking up the survivor subject position, 
which is more associated with a sense of strength, struggle, and bravery (Lamb 1999; Warner 2001).

Employing these Foucauldian thoughts, poststructuralist scholars have identified a problematic discursive construction underpinning CSA, namely, the binary positioning of adults as powerful and sexually exploitative, and children as sexually innocent and powerless (Angelides 2004; Burman 2003; Clark 2014; Egan and Hawkes 2009; Grondin 2011; Lamb and Plocha 2014). As Angelides (2004) has noted, this discursive positioning has expanded since the 1980s, when feminists fought to overturn the tendency to blame victims of CSA. On the one hand, this discursive positioning has given rise to various social movements and legal measures protecting children from sexual abuse (Angelides 2004; Warner 2001). On the other hand, this dominant construction has also constituted ways-of-seeing that deny children's sexual agency and fail to recognize them as sexual subjects (Burman 2003; Egan and Hawkes 2009); or, in short, the erasure of child sexuality (Angelides 2004). The terms used to refer to children's sexual expressions, for example, often imply a trivialisation of their sexuality, such as "sex play" and "sexual experimentation" (Angelides 2004). Largely based on adult-oriented views on sexuality, children are desexualized and infantilized (Burman 2003) as if they are not sexual beings. This representation of children, however, is flawed and unrepresentative (Egan and Hawkes 2009), and confines children to the (potential) victim subject position. Through this positioning, it becomes "normal" to view children as always in need of protection, because they are constituted as unable to understand and make decisions concerning sexuality while adults around them are constituted as powerful, exploitative, and may sexually abuse children at any time. Drawing on this notion of protection, excessive surveillance on children has often been accepted as "normal," such as in the Jakarta International School case above where more than 400 cameras were installed in the school with the belief that this would help prevent CSA (Rahmawati 2014).

In contrast to this positioning of children as sexually innocent, other studies have shown that children express interest in, experiment with, and make meaning out of their sexual experiences. In other words, they are sexual subjects. Studies have indicated that children express sexual interest and engage in sexually-related behaviours with other children long before puberty (Lamb and Plocha 2014). Historically, Foucault (1978) identified that, in the nineteenth century, children were not constituted as asexual or sexually innocent, but as having sexual potential and often indulging in masturbation. In terms of man-boy sexual relationships, Yuill and Durber (2008) reviewed studies that have demonstrated how boys have been given meaning to their sexual experiences-in retrospect-through the notions of autonomy, assertiveness, and rights of sexual expression. Other studies documented how "survivors" of CSA were not always completely passive and powerless; some feel that they did make choices, however small, that led to the initial incident and its continuation (Lamb 1986). These choices include returning to the "perpetrator's" home or seeking gifts by engaging in sexual activities (Angelides 2004). In a study of older children's and teenagers' sexual relationships with adults, Phillips (1999) showed that her participants often reported a sense of initiation, willingness, and decision-making in these relationships. These studies evidenced that children can be, and have been, 
constituted as sexual subjects who actively make meaning and exercise agency. This does not mean that children's possibility of exercising power is relatively equal with adults, or that they are thus fully responsible for their own participation in a sexual activity with an adult. What I want to foreground here is that, within the network of power relations that continuously deny children as sexual subjects and constrain their agency, there is evidence that they are meaning-givers and construers of their own sexual experience (Lamb and Plocha 2014), and-to a limited degree-that they make decisions in their sexual engagements (Angelides 2004; Lamb 1986; Phillips 1999).

Addressing this situation, scholars in this area have proposed some careful suggestions. Without undermining valuable efforts to protect children from violence and abuse, Egan and Hawkes (2009) recommended that firstly, children must be recognized as sexual subjects who actively make meanings about sexuality and exercise agency. Completely denying children's sexual agency might reinforce the idea that they are always lacking in power and control in any interaction with adults, including sexually-related interaction. By acknowledging children as sexual subjects, more spaces might be opened up to talk about, examine, and explore discursive resources that can be drawn on to expand children's exercise of power. Secondly, children's sexuality needs to be uncoupled from the adult-oriented model (Egan and Hawkes 2009). This means that children's sexuality must be acknowledged, not as trivial or merely a projection of adult sexuality, but as unique in its own right, including its multiple sexual expressions such as children's "sex play." Thirdly, adults must cease using the notion of protection as an excuse to legitimize surveillance and excessive control over children. Rather, children need to be encouraged to build ethical and respectful relationships as early as possible (Robinson 2013), but without assigning responsibility to them for their participation in a sexual activity. Currently, knowledge and examples of various ways children ethically negotiate consent, desire, and pleasures in specific discursive contexts of their sexual relationships are still lacking (Carmody 2015). This article seeks to fill this gap, that is, by fleshing out these suggestions in the narratives of children's sexual interaction with adults, and thus call into question the binary of adults' (sexual) powerfulness and children's (sexual) powerlessness underpinning the discourse of CSA (Angelides 2004). In the Findings and Discussion section I will demonstrate in what ways children might be positioned as sexual subjects and how ethical sexual negotiations might have been engaged by children.

\section{Methodology}

The data analysed in this study are a part of my doctoral research on Indonesian young people's sexual subjectivities. I interviewed 22 Indonesian young people aged 16-24 about their ways of being sexual, and during the interviews some of them shared their experience of CSA. At the time of the interview, 6 participants were high school students, 8 were college students, 5 were in employment, 1 was a postgraduate student, 1 was a freelance journalist, and 1 was an NGO activist. Most participants were heterosexual (14 participants); others included gay (4 participants), 
lesbian (2 participants), bisexual (1 participant), and asexual (1 participant). In term of gender, 12 participants identified as male, 9 female, and 1 neither gender. Most participants are from urban middle-class families, and no participants were married. These participants were recruited through advertisements sent to NGOs, universities, and communities in several cities in Indonesia. To maintain confidentiality, the names of these cities, organisations, and communities are not disclosed. The minimum age of participant was set on 16 so they can participate without parental consent. This means that their narratives of CSA in this article were based on their memory when they were older. All participant names are pseudonyms.

The data were collected using computer-mediated communication (CMC) research methods, that is, semi-structured online interview (email and instant messenger) and autobiographical writing. CMC research methods offer advantages which are relevant with this research such as (1) providing psychological comfort and security to explore sensitive topics (McCoyd and Kerson 2006), (2) encouraging a more reflective engagement with the topic as compared to face-to-face interview, which in turn promotes a more equal and collaborative relationship with the researcher (James 2016), and (3) offering some practical advantages (Mann and Stewart 2000) such as saving travel costs because the participants were from various geographical locations. The online interviews involved 10-20 email exchanges over 4-12 weeks with each participant, and one session of instant messenger chat. After the interviews, the participants wrote and emailed a short autobiographical essay about their sexualities. Narratives presented in this article were translated into English by the researcher because all interviews were conducted in participants' first language, that is, Bahasa Indonesia.

\section{Findings and Discussion}

This Findings and Discussion section examines narratives from three young Indonesians who have engaged in sexual interaction with adults when they were children (under 18 years old). Their experiences correspond with the definition of CSA used in this research. One narrative involves sexual violence and two others do not indicate the presence of force, coercion, or threat. I will firstly demonstrate how these participants have drawn on this binary in giving meaning to their experience. Subsequently, I will explore how their alternative subjectivities might resist dominant meanings circulated by this dominant construction of children and adults.

One participant who experienced violent CSA as a child was Putri, a 22-yearold college student when participating in this research. In term of gender identity, Putri self-identified as neither gender. As a child, Putri had several sexual experiences with adults, which Putri characterized as coercive and causing negative consequences. Below is Putri's story which shows how this binary has been drawn on in Putri's understanding of CSA:

I was harassed several times by different people since I was in elementary school: a friend of my uncle, two female cousins from another town, and another female cousin from my hometown who asked me to oral her body. 
All these have left scars in my heart. But the one that traumatized me was my parents' employee. Same person, three times, at my house, when nobody's home. He knew that I cannot do anything when someone yelled at me. When my parents found out, they never leave me alone at home anymore. ... Since then, I hate the penis. I feel nauseous every time I see any thick liquid. This experience made me think that all men are bastards. I really hate men, sex, and marriage - I am afraid of all those things. I am afraid to marry. I am afraid and hate sexual relationships with men, because it's always painful for me. Their world is cruel. They can ask and force others to do anything they want. They touched all my body without feeling guilty. I was just a 12-year-old kid, they should protect and care for me. But they treated me as their sexual object, to satisfy their evil lust. (autobiographical writing)

As seen in this narrative, these incidents of CSA when Putri was young have shaped the way Putri gives meaning to understanding sex and sexual selves. Putri describes how those incidents have been deeply and permanently wounding ("traumatized me," "left scars in my heart"). Putri's feelings about "men, sex, and marriage" were marred because of these experiences of violent CSA. Although also harassed by women (three female cousins), Putri was particularly "traumatized" by the sexual abuse by a man (i.e., Putri parents' employee). As a result, Putri is both "afraid of" and "hate[s]" men. Putri cannot stand seeing a penis, and even "any thick liquid" can invoke a "nauseous" feeling.

Underpinning Putri's account of this experience of CSA is the binary of adults (in this case adult men) as powerful/sexually exploitative and children as powerless/ innocent. Putri believes that "all men are bastards," particularly in terms of their exploitative character ("they touched all my body without feeling guilty"). Putri describes adult men as sexually predatory, are full of "evil lust," and "cruel," and Putri's relationships with them were always "painful." Putri also views adult men as powerful and unstoppable ("they can ask and force others to do anything they want."). In contrast, Putri describes the child in this situation as innocent and in need of protection ("I was just a 12-year-old kid, they should protect and care for me"). Putri uses the word "sexual object" to illustrate how those adults have treated their victim - which implies a sense of passivity, powerlessness, and lack of agency. During the incident Putri "[could not] do anything" when the perpetrator yelled, because he knew it would immobilize Putri. Drawing on this binary, the solution taken by Putri's parents was by not leaving Putri alone at home anymore - an adult had to stay with Putri to provide protection at all times. While it has evidently given Putri a degree of protection, this prevention method further normalized the belief that adults are powerful and children are powerless and vulnerable.

In contrast to Putri's story, there are other participants whose narrative might contest the positioning of adults and children through this binary. The 17-year-old high school student Daniel, for example, narrated his experience of sex with an adult when he was 12 years old (and unable to give sexual consent according to the Indonesian law), therefore, may be considered as CSA.

When I was 12 years old there were two female seminary students from another town came to my church to do their internship. I was interested in one 
of them because she had a pretty face and a sexy body. After one month we were involved in church activities together, we engaged in this sexual sin. It started when we were alone in the church's music studio. At that time we were just looking at paintings on the wall. Then I approached her, and I don't know why I just suddenly had the courage to kiss her cheek. She looked at me. I was terrifyingly afraid. But then she suddenly pulled me and kissed my lips. We kissed, and then she led me to the church attic to do something more. I was confused and afraid she might get pregnant. I asked her and she said she was on the pill so she won't get pregnant. Then we had sex there. For the next three months, we did it almost every day in her bedroom within the church area. I told my friends at school and my cousins about it (but not my friends at church) and it made me feel proud. I didn't feel ashamed at all. After a while I started to feel bored with her and I ditched her by coming only when I wanted sex. One day she said her internship was almost finished and she would soon return to her hometown. I was happy because finally I would be free from the commitment and responsibility. I distanced myself from her by saying I wanted to repent from this sin, and also because she was six years older than me. She was upset and perhaps bitterly angry with me, because one week before she left I didn't talk to her at all. Later, after she left I felt guilty. I tried to apologize but I wasn't able to contact her. (autobiographical writing)

This narrative presents a sexual relationship between Daniel as a teenager and a woman who was 6 years older than him. This narrative does not involve one person using violence, force, or threats to make the other person engage in sex. Rather, it involves two persons who were willingly engaged in a sexual relationship, but one of them was considered unable to give consent because of his age. Daniel's narrative might offer some possibilities to contest the construction of adults as powerful/ exploitative and children as innocent/powerless, that is, by reversing and/or complicating this binary. Additionally, I will also discuss an example of ethical negotiations in Daniel's sexual relationship (Carmody 2003, 2015).

Daniel's story troubles the binary of adults as powerful/sexually exploitative and children and teenagers as innocent/powerless, because as the teenager in this narrative he did not show sexual innocence and powerlessness. Daniel considers himself as the one who had the first physical/sexual interest in the other person ("I was interested in one of them because she has a pretty face and a sexy body"). He also initiated the first intimate physical contact (i.e., "kissing her cheek"). Different from the teenage participants in Phillips' (1999) study who agentically made a decision to enter the relationship but struggled to maintain and exit the relationship, Daniel was able to make decision both to initiate and end the relationship ("I started to feel bored with her and I ditched her"). This showed how Daniel is not the passive or powerless partner in this relationship, but rather, to a degree he has taken up the role of the active and desiring agent. A discourse of men as sexually desiring might have enabled Daniel to give such meaning to his sexual self. Daniel's bragging about his sexual experience ("I told my friends ... and it made me feel proud"), for instance, might indicate his accommodation of the gendered meanings of sex-in which for young women it is shame and guilt and for young men it is pride and joy (Holland 
et al. 2000). By drawing on this discourse, Daniel has been enabled to understand himself as a desiring sexual subject, and thus disrupted the positioning of adults as powerful/exploitative and children and teenagers as innocent/powerless.

However, Daniel might not be the only active and desiring agent in the relationship. As Johnson (2010) has demonstrated, female adults in her study did not directly initiate sexual relationship with the young male teenager. Rather, they set up situations where intimate relationships could take place, so that they can just passively give into the temptation. Without Daniel's awareness, the seminary student might have been "preying" on him and staged situations where Daniel could make his first move. Why were they looking at paintings alone in a sound-proof church music studio (instead of practising music or doing rehearsal)? Why was she on contraceptive pills if she had no plan to engage in sex? As Phillips (1999) has identified among her participants, teenagers may not realize the problems with their relationship with adults when they were in the relationship, but after the relationship ended they can look back and see how the relationship was, in some ways, exploitative. This possibility showed that the binary of adults as exploitative/powerful and children as innocent/powerless is not as clear-cut as claimed, but there are complexities within an adult-teenager sexual relationship that cannot be accommodated by this binary. Daniel was not the powerless one all the time, and the seminary student was not the powerful all the time. Both of them might have exercised varying degrees of sexual agency in different moments.

Further, what I am more interested in, in terms of analysing Daniel's narrative, is the possibility of ethical negotiation in his sexual relationship. Here, I attempt to flesh out Carmody's (2003, 2015) proposal of building ethical relationships, and Egan and Hawkes's (2009) suggestion of recognizing children as agentic sexual subjects. To date, an analysis of these proposals in the narrative of a sexual experience is barely available in the existing literature. I am focusing on how a recognition of Daniel as sexual subject (who has desire and agency, who is enabled/constrained by discourses) has made possible a form of ethical negotiation.

In Daniel's narrative there are examples of negotiation between Daniel and the seminary student around sex, desire, and ethics. Within the limited discursive resources he had access to, Daniel negotiated his sexual desire toward the seminary student by considering a possibility of a consensual relationship. Daniel kissed her on the cheek-which in the Indonesian context can be an expression of affection and/or sexual gesture. His state of being "terrifyingly afraid" after the kiss indicated his lack of certainty and lack of intentionality. The pause after the kiss shows that Daniel expected a response, which could be an angry slap, a turning away, or a return kiss. This subtle cycle of initiation and response represent a kind of conversation or negotiation. Here I do not suggest that this kissing on the cheek without asking is always ethical. My point is that, within Daniel's limited knowledge, vocabularies, and experience to express his desire, this kiss might have been the most ethical move he could think of, and do, in that moment.

After the initiation and the "consenting" response, their sex had not then "just happened" but there were other negotiations. They avoided the possibility of people discovering them having sex, by moving to the church attic. This time the seminary student initiated ("she led me to the church attic"), and Daniel's response was to 
follow her lead. In the attic, they did not just become "carried away" by engaging in sex, but Daniel asked about a possible consequence of their sex, that is, pregnancy. Only after the seminary student assured him it would not happen, they then engaged in sex. By considering possible consequences such as pregnancy and people discovering them having sex, Daniel and the seminary student have engaged in a kind of ethical negotiation in terms of openness, honesty, and care of the self and others.

However, Daniel's narrative also exhibits examples of unethical acts in the relationship. Daniel's bragging about his sex might not be considerate toward the seminary student's feeling. Daniel dealt with his boredom ("feel bored with her"), selfcentredness ("coming only when I want sex"), and avoidance of "commitment and responsibility" by ditching the seminar student instead of ethically negotiating it with her. As Carmody (2003) has noted, building ethical sexual relationships cannot just about a one-off consent, but continuous negotiations-which make room for new dynamics and changes throughout the relationship. Daniel himself realized his unethical actions and attempted to apologize, but unfortunately he could not find her.

In the constitution of his sexual subjectivity, Daniel's story has shown a contestation toward the discourse of CSA in at least two ways. Firstly, his narrative has shown that the binary of adults as powerful/sexually exploitative and children and teenagers as innocent/powerless might be too simplistic and unrepresentative. Secondly, his narrative substantiates Egan and Hawkes's (2009) argument that the possibility of ethical negotiations could not take place unless children and teenagers are recognized as sexual subjects. Negotiations between Daniel and the seminary student can be constituted as negotiations in this analysis because both of them are understood as sexual subjects who are able to make decisions and exercise agency (Davies 1991). The subject positions they occupied might not grant them exactly the same possibilities to exercise power, but — as their narrative has shown-it does not mean there is no space for ethical negotiation. In so doing Daniel's narrative resisted the erasure of child sexuality through the discourse of CSA.

While Daniel's story occured when he was 12 years old, the final narrative I will examine in this article, Hardi's story, occured at a much earlier age. Hardi, a 22-year-old office worker, narrated his experiences of sexual interaction with adults since he was 5 years old. His age at that time was far below the legal age of sexual consent; so, by definition, it is a CSA. Below is his narrative which indicates a possibility of child sexual agency, and thus, might further challenge the binary of adult as powerful/exploitative and children as innocent/powerless:

Hardi: It all started when I was 5 years old. I already experienced sexual harassment, but I just enjoyed it. At that time my mom worked in a rural town. One day I was invited by a young guy in that neighbourhood. He asked me to hold his penis. I did what he said till his fluid came out. I didn't know what fluid it was, but I just enjoyed it. This happened repeatedly, including my friends at the same age with me asked me to do that too.

Then my family moved to another city. There, I experienced the same thing. Young men there invited me to do the same, and I just enjoyed it. I was also asked to oral his penis and I did it. 
I did all those things but I have not yet experienced the peak. Until one day I also can feel how pleasurable it was when that white fluid came out. My intermediate and high schools were the time when I really enjoyed such activities. Almost every day I masturbated and did same-sex activities like that.

Thanks to God after high school, uni, and until now I am not bound to those sins like I was. It's all because of my struggles with God so that I can leave all those sinful deeds.

Teguh: I know it has been long time ago, but as far as you can remember, were you "forced", or "invited by them and then you were willing"? Or perhaps it's hard to describe that experience in these ways? And how do you feel about those experiences now? Like, do you hate those young men, or do you feel nothing?

Hardi: As far as I remember, I was playing around the neighbourhood, then a young guy invited me, and I don't know why, I just followed him. At that time I was only 5 years old, if I'm not mistaken. My feeling now? Just ordinary. I remember at that time I just enjoyed it without knowing what I was doing. I never hated those guys. I don't know where they are now, and I don't care. I totally forget it. (email interview)

On the one hand, Hardi's subjectivity in this narrative can be seen as both informed by and reproducing the binary of adults as powerful/exploitative and children as innocent/powerless. As a child Hardi has "innocently" engaged in sexual activities since he did not know what was happening ("I don't know why, I just followed him," "without knowing what I was doing," "I didn't know what fluid it was"). To some extent Hardi also showed a lack of agency at that time, in which he described himself as "just following" what those adults asked him to do. Correspondingly, the adult men in this narrative were the ones who initiated and controlled the sexual interactions. They can be seen as exploitative in the way they made Hardi hold and insert their penis in his mouth for their own sexual pleasure.

On the other hand, there are some complexities within his sexual subjectivity which might pose a disruption toward the binary of children as powerless and adults as powerful. One of these complexities is Hardi's lack of reference both to his experience as sexual abuse and to himself as a coerced or manipulated victim of CSA. Other than a mention of "sexual harassment" at the beginning of his story, Hardi did not use words like "threaten," "forced," or "unwilling" in articulating his experience. Instead, he used words such as "invited" and "followed him," even after I intentionally juxtaposed the word "forced" and "invited" and asked him to choose. I will argue below that Hardi's lack of reference to sexual abuse or victim subject position is an agentic exercise of power-which might resist the positioning of children as innocent and powerless.

Before I proceed, it is crucial to clarify that in this analysis I do not intend to justify or condone the incidents Hardi experienced. My aim is to identify 
alternative ways-of-seeing and ways-of-being that might disrupt the binary of adult as powerful/exploitative and children as innocent/powerless. I will explore the possibility of Hardi's exercise of agency as sexual subject when he was a child-not as a means to claim consensuality or locate his responsibility for participating. Instead, my intention is to acknowledge him as a sexual subject who exercises agency, however minimal. I will demonstrate both possibilities and limitations of the way Hardi understands his sexual experience from the subject position he occupied. My purpose is that this analysis might challenge the logic underpinning the discourse of CSA, that is, the positioning of adults and children through this binary.

Different from the violent CSA case in Jakarta International School I described earlier where the child was unwilling and was then threatened by the adult perpetrator, Hardi's way of narrating his experience does not show a sense of violence, unwillingness, or feelings of being threatened. Hardi refused to employ the term "forced" that I offered in the interview-a word which implies a sense of victimization and non-consensuality. Rather, he prefers the term "[he] invited me, and ... I just followed him," which implies a sense of willingness and a non-forceful act. Hardi did not draw on the meanings offered by the discourse of CSA, which constituted his experience as sexual abuse and thus positioned him as the victim. Hardi's alternative sexual subjectivity resisted the positioning of him as the victim and, more generally, children as powerless by showing the possibility of exercising a degree of agency.

By understanding Hardi's lack of reference to sexual abuse as agentic resistance, possibilities and limitations afforded by his subject position might be explored. If Hardi recognized his experience as CSA, he is immediately "hailed" or positioned as the victim or the survivor-with its discursive meanings that enable and constrain his ways of being a sexual subject. A victim subject position, for instance, necessitates a sense of helplessness, a devastated condition, a need to be healed, a call for external support and help (Jordan 2013; Lamb 1999; Malón 2009; Oellerich 2002). The survivor position offers a better sense of agency, but that agency is built around the specific experience of sexual abuse. Such positioning as survivor, in turn, reproduces the centrality of the incident of CSA in one's sense of self throughout their lives (Dunn 2005; Nielsen 2016; Warner 2001). By refusing to take up these positions, Hardi's subjectivity is not confined to these limited ways of seeing himself as a sexual subject. He is enabled to feel "just ordinary" and "[didn't] care" about the perpetrators and the experience. He is not forever haunted by their "abuse" and feelings associated with it such as anger, sadness, a feeling of being victimized, or a need to forgive and to be resilient. He was able to just "totally forget it." However, it is important to note that I do not claim that the subject position Hardi occupies is always "better" or more "beneficial" in any kinds or contexts of CSA. While this position limits him in many ways (e.g., from getting professional help, or more protection from parents), what I intend to highlight here is that it also opens up other possibilities for him (e.g., to not being positioned as powerless victim with those various meanings attached to it).

Another possibility afforded by Hardi's subject position in relation to CSA is his resistance toward the "trauma of sexual abuse" discourse-in which the impact of 
sexual abuse is constituted as always traumatic and devastating (Gavey and Schmidt 2011), or what Malón (2009) called the politics of victimization. Throughout the interviews Hardi did not blame the "perpetrator" nor refer to this experience as problematic in his journey of becoming a sexual subject. Hardi represents “... many sexually abused children who are apparently asymptomatic" (Kendall-Tackett et al. 1993, p. 30). Instead of victimization, Hardi's "struggle" is to repent from "sinful deeds" such as "masturbation" and "same-sex [sexual] activity," which he attributed to human's sinful nature as he understood from his religion. In a way, Hardi's story has brought Marcus's (2002) call—to refuse the idea that the (devastating) impact of sexual abuse is self-explanatory-into being.

Instead of "devastating," Hardi articulates those sexual experiences with adults as pleasurable. Hardi used and repeated a phrase "I just enjoyed it" at least four times in this narrative to describe his sexual experience with adults. This finding offers an example of children's capacity for pleasure in a sexual interaction (Foucault 1978; Lamb and Plocha 2014). It also challenges the erasure of childhood sexuality implicated in the discourse of CSA (Angelides 2004). This narrative demonstrates that children are sexual subjects who make meaning out of their experiences. Continuously denying their agency and sexual capacity through the discourse of CSA could further confine them into (potential) victim subject positions. Such denial could also make them feel guilty or betrayed by their body when they felt pleasure in their sexual interactions with adults (Allen 2012; Angelides 2004).

Hardi's narrative has shown a possibility for resistance towards the discourse of CSA in the constitution of his sexual subjectivity. His alternative subjectivity disrupts: (1) the discursive positioning of children as innocent and powerless, (2) the dominant construction of the devastating effect of CSA, and (3) the continuous denial to recognize children as legitimate sexual subjects. In this way, Hardi's narrative may contribute to the enactment of Gavey's (1999) call for more complex and less certain constitutions of sexual abuse and its effects. This means that all kinds of children's interpretations of their sexual experience with adults and its effects are acknowledged and examined.

\section{Conclusion}

In this article I have identified and examined how a discursive construction, namely, the binary positioning of adult as powerful/exploitative and children as powerless/ innocent has been both drawn on and resisted by the participants in the constitution of their sexual subjectivity. I have focused on how this discursive positioning might be disrupted and destabilized in the constitution of children as agentic sexual subjects. In highlighting these resistances I do not intend to approve/disapprove the examples of adult-children sexual interaction presented here. Instead, I seek to complicate the dominant meanings around and the underlying logic of CSA by using these narratives. The findings contribute new analyses of vignettes of everyday experiences to the existing body of knowledge on the critiques towards the discourse of CSA. 
The implications of this analyses are twofold. Firstly, parents, teachers, and sexual educators might find benefit in starting to recognize children as sexual subjects. By acknowledging that children are sexual being who make meaning out of their experiences, more (discursive) resources might be explored to expand the possibility of their exercise of agency. To this end, further studies are needed to listen to and explore children's various ways of understanding their sexualities and the discourses they draw upon. Secondly, this study calls for counselors dealing with CSA cases to accommodate children's complex and multiple ways of being sexual. Such accommodation may consider and include children's capacity for ethical sexual exploration, negotiation, and pleasure. In so doing the iatrogenic harm in relation to expectancy effect (i.e., the child is constituted as victim and, thus, is expected to experience negative consequences) given rise by the discourse of CSA might be minimized.

Acknowledgements This work was made possible by the Indonesian Directorate General of Higher Education (DIKTI) under Beasiswa Luar Negeri (BLN) scholarship scheme.

\section{Compliance with Ethical Standards}

Conflict of interest This article is part of the author's doctoral research that was funded by Indonesian Directorate General of Higher Education (DIKTI) under Beasiswa Luar Negeri (BLN) scholarship scheme. Author's view in this article does not represent the funder's nor his university's view.

Human and Animal Rights All procedures performed in studies involving human participants were in accordance with the ethical standards of the institutional and/or national research committee and with the 1964 Helsinki declaration and its later amendments or comparable ethical standards. Ethical approval was granted by the university's ethics committee (ref number 9046) where the author studied his doctorate. This article does not contain any studies with animals performed by any of the authors.

Informed Consent Informed consent was obtained from all individual participants included in the study.

\section{References}

Aisyah, S., \& Parker, L. (2014). Problematic conjugations: Women's agency, marriage and domestic violence in Indonesia. Asian Studies Review, 38(2), 205-223. https://doi.org/10.1080/10357 823.2014.899312.

Allen, L. (2012). Pleasure's perils? Critically reflecting on pleasure's inclusion in sexuality education. Sexualities, 15(3-4), 455-471. https://doi.org/10.1177/1363460712439654.

Angelides, S. (2004). Feminism, child sexual abuse, and the erasure of child sexuality. GLQ: A Journal of Lesbian and Gay Studies, 10(2), 141-177. https://doi.org/10.1215/10642684-10-2-141.

Bennett, L. R., Andajani-Sutjahjo, S., \& Idrus, N. I. (2011). Domestic violence in Nusa Tenggara Barat, Indonesia: married women's definitions and experiences of violence in the home. The Asia Pacific Journal of Anthropology, 12(2), 146-163. https://doi.org/10.1080/14442213.2010.547514.

Berfield, S., \& Loveard, D. (1998). Ten days that shook Indonesia, Asia Week. Retrieved from http:// www-cgi.cnn.com/ASIANOW/asiaweek/98/0724/cs1.html.

Blackburn, S. (1999). Gender violence and the Indonesian political transition. Asian Studies Review, 23(4), 433-448. https://doi.org/10.1080/10357829908713249.

Boothby, N., \& Stark, L. (2011). Data surveillance in child protection systems development: An Indonesian case study. Child Abuse and Neglect, 35(12), 993-1001. https://doi.org/10.1016/j.chiab u.2011.09.004. 
Burman, E. (2003). Childhood, sexual abuse and contemporary political subjectivities. In P. Reavey \& S. Warner (Eds.), New feminist stories of child sexual abuse: Sexual scripts and dangerous dialogue (pp. 34-51). London: Routledge.

Carmody, M. (2003). Sexual ethics and violence prevention. Social \& Legal Studies, 12(2), 199-216. https://doi.org/10.1177/0964663903012002003.

Carmody, M. (2015). Sex, ethics, and young people. New York: Palgrave Macmillan.

Clark, J. (2014). Sexualisation and the discursive figure of the child. In M. N. Warehime (Ed.), Soul of society: A focus on the lives of children \& youth (pp. 173-197). Emerald: Bingley.

Davies, B. (1991). The concept of agency: A feminist poststructuralist analysis. Social Analysis, 30, 42-53. Retrieved from http://www.jstor.org/stable/23164525.

Dunn, J. L. (2005). "Victims" and "survivors": Emerging vocabularies of motive for "battered women who stay. Sociological Inquiry, 75(1), 1-30. https://doi.org/10.1111/j.1475-682X.2005.00110.x.

Egan, R. D., \& Hawkes, G. (2009). The problem with protection: Or, why we need to move towards recognition and the sexual agency of children. Continuum: Journal of Media \& Cultural Studies, 23(3), 389-400. https://doi.org/10.1080/10304310902842975.

Felten-Biermann, C. (2006). Gender and natural disaster: Sexualized violence and the tsunami. Development, 49(3), 82-86. https://doi.org/10.1057/palgrave.development.1100276.

Finkelhor, D. (1999). Child sexual abuse: Challenges facing child protection and mental health professionals. In E. Ullmann \& W. Hilweg (Eds.), Childhood and trauma: Separation, abuse, war (pp. 101-115). Aldershot, England: Ashgate.

Finkelhor, D., Shattuck, A., Turner, H. A., \& Hamby, S. L. (2014). The lifetime prevalence of child sexual abuse and sexual assault assessed in late adolescence. Journal of Adolescent Health, 55(3), 329-333. https://doi.org/10.1016/j.jadohealth.2013.12.026.

Foucault, M. (1972). The archaeology of knowledge and the discourse on language (A. M. S. Smith, Trans.). New York: Pantheon Books.

Foucault, M. (1978). The history of sexuality, vol. 1: The will to knowledge (R. Hurley, Trans.). New York: Pantheon Books.

Foucault, M. (1982). The subject and power. Critical inquiry, 8(4), 777-795.

Foucault, M. (1985). The history of sexuality, vol. 2: The use of pleasure (R. Hurley, Trans.). New York: Pantheon Books.

Gavey, N. (1999). "I wasn't raped, but ...": Revisiting definitional problems in sexual victimization. In S. Lamb (Ed.), New versions of victims: Feminists struggle with the concept (pp. 57-81). New York: NYU Press.

Gavey, N., \& Schmidt, J. (2011). "Trauma of rape" discourse: A double-edged template for everyday understandings of the impact of rape? Violence Against Women, 17(4), 433-456. https://doi. org/10.1177/1077801211404194.

Green, J. L. (2004). Uncovering collective rape: A comparative study of political sexual violence. International Journal of Sociology, 34(1), 97-116.

Grondin, A.-M. (2011). Thinking outside specious boxes: Constructionist and post-structuralist readings of 'child sexual abuse'. Sex Education, 11(3), 243-254. https://doi.org/10.1080/14681 811.2011.590065.

Haditono, S. R. (1981). Prevention and treatment of child abuse and neglect among children under five years of age in Indonesia. Child Abuse and Neglect, 5(2), 97-101. https://doi.org/10.1016/01452134(81)90026-0.

Hayati, E. N., Högberg, U., Hakimi, M., Ellsberg, M. C., \& Emmelin, M. (2011). Behind the silence of harmony: Risk factors for physical and sexual violence among women in rural Indonesia. BMC Women's Health, 11(1), 52-59. https://doi.org/10.1186/1472-6874-11-52.

Holland, J., Ramazanoglu, C., Sharpe, S., \& Thomson, R. (2000). Deconstructing virginity-young people's accounts of first sex. Sexual and Relationship Therapy, 15(3), 221-232. https://doi. org/10.1080/14681990050109827.

James, N. (2016). Using email interviews in qualitative educational research: Creating space to think and time to talk. International Journal of Qualitative Studies in Education, 29(2), 150-163. https ://doi.org/10.1080/09518398.2015.1017848.

Johnson, T. S. (2010). Crossing the line: When pedagogical relationships go awry. Teachers College Record, 112(8), 2021-2066. Retrieved from http://www.tcrecord.org/library/abstract.asp?conte ntid=15922. 
Jordan, J. (2013). From victim to survivor-and from survivor to victim: Reconceptualising the survivor journey. Sexual Abuse in Australia and New Zealand, 5(2), 48-56. Retrieved from http://search.infor mit.com.au/documentSummary;dn=832896370790754;res=IELNZC.

Kendall-Tackett, K. A., Williams, L. M., \& Finkelhor, D. (1993). Impact of sexual abuse on children: A review and synthesis of recent empirical studies. Psychological Bulletin, 113(1), 164-180. https:// doi.org/10.1037/0033-2909.113.1.164.

Lamb, S. (1986). Treating sexually abused children: Issues of blame and responsibility. American Journal of Orthopsychiatry, 56(2), 303-307. https://doi.org/10.1111/j.1939-0025.1986.tb02730.x.

Lamb, S. (1999). Constructing the victim: Popular images and lasting labels. In S. Lamb (Ed.), New versions of victims: Feminists struggle with the concept (pp. 108-138). New York: NYU Press.

Lamb, S., \& Plocha, A. (2014). Sexuality in childhood. In D. L. Tolman, L. M. Diamond, J. A. Bauermeister, W. H. George, J. G. Pfaus, \& L. M. Ward (Eds.), APA handbook of sexuality and psychology, vol 1: Person-based approaches (pp. 415-432). Washington, DC: American Psychological Association.

Liauw, H. (2014, June 10). Masyarakat bergerak, pemerintah malah pasif (People have moved, government still passive), Kompas. Retrieved from http://megapolitan.kompas.com/read/2014/06/10/20325 13/Masyarakat.Bergerak.Pemerintah.Malah.Pasif.

Malón, A. (2009). On the iatrogenic nature of the child sexual abuse discourse. Sexuality and Culture, 13(2), 75-90. https://doi.org/10.1007/s12119-009-9045-2.

Mann, C., \& Stewart, F. (2000). Internet communication and qualitative research: A handbook for researching online. London: SAGE.

Marching, S. T. (2007). The mass rape of the ethnic Chinese in May 1998 and the war on terror. Pacific News, 27. Retrieved from http://www.pacific-geographies.org/wp-content/uploads/sites/2/2017/06/ pn27_marching.pdf.

Marcus, S. (2002). Fighting bodies, fighting words: A theory and politics of rape prevention. In C. L. Mui \& J. S. Murphy (Eds.), Gender struggles: Practical approaches to contemporary feminism (pp. 166-185). Lanham: Rowman \& Littlefield.

McCoyd, J. L. M., \& Kerson, T. S. (2006). Conducting intensive interviews using email: A serendipitous comparative opportunity. Qualitative Social Work, 5(3), 389-406. https://doi.org/10.1177/14733 25006067367.

Murray, L. K., Nguyen, A., \& Cohen, J. A. (2014). Child sexual abuse. Child and Adolescent Psychiatric Clinics, 23(2), 321-337. https://doi.org/10.1016/j.chc.2014.01.003.

Nielsen, M. F. (2016). When compassion is making it worse: Social dynamics of tabooing victims of child sexual abuse. Sexuality and Culture, 20(2), 386-402. https://doi.org/10.1007/s12119-015-9329-7.

Oellerich, T. (2002). The case against the routine provision of psychotherapy to children/adolescents labeled "sexually abused". Sexuality and Culture, 6(2), 3-24. https://doi.org/10.1007/s1211 9-002-1001-3.

Perempuan, K. (2009). Perempuan dalam jeratan impunitas: Pelanggaran dan penanganan (Women in the entrapment of impunity: Infringement and treatment). Jakarta.

Phillips, L. M. (1999). Recasting consent: Agency and victimization in adult-teen relationships. In S. Lamb (Ed.), New versions of victims: Feminists struggle with the concept (pp. 82-107). New York: NYU Press.

Rahmawati, L. (2014, April, 15). Punya 400 CCTV, JIS tetap kecolongan (Had 400 CCTV, JIS still missed the incident), Kompas. Retrieved from http://megapolitan.kompas.com/read/2014/04/15/1927566/ Punya.400.CCTV.JIS.Tetap.Kecolongan.

Robinson, K. H. (2013). Building respectful relationships early: Educating children on gender variance and sexual diversity. A response to Damien Riggs. Contemporary Issues in Early Childhood, 14(1), 81-87. https://doi.org/10.2304/ciec.2014.14.1.81.

Saleh, R. (2014, May 19). Indonesia darurat kejahatan seksual terhadap anak (Sexual violence against children: Indonesia in a state of emergency), Kabar24. Retrieved from http://kabar24.bisnis.com/ read/20140519/79/229045/indonesia-darurat-kejahatan-seksual-terhadap-anak.

Sari, H. R. (2014, April 14). Bocah TK disodomi petugas kebersihan JIS (Kindergarten kids sodomised by cleaner at JIS), Merdeka. Retrieved from http://www.merdeka.com/jakarta/bocah-tk-disodomipetugas-kebersihan-jis.html.

Syahni, M. (2014, June 11). Belajar dari kasus JIS, KPPA dan DPR revisi UU perlindungan anak (Learning from JIS case, KPPA and Parliament will revise child protection law), Kompas. Retrieved from http://nasional.kompas.com/read/2014/06/11/1125260/Belajar.dari.Kasus.JIS.KPPA.dan.DPR.Revis i.UU.Perlindungan.Anak. 
Undang-undang Republik Indonesia no 35 tahun 2014 tentang perlindungan anak (Republic of Indonesia Law no 35 year 2014 about child protection) (2014).

UNICEF. (2010). Definitions of select child protection terms. Retrieved from https://www.unicef.org/ protection/57929_58022.html.

Wandita, G. (1998). The tears have not stopped, the violence has not ended: Political upheaval, ethnicity, and violence against women in Indonesia. Gender \& Development, 6(3), 34-41. https://doi. org/10.1080/741922832.

Warner, S. (2001). Disrupting identity through visible therapy: A feminist post-structuralist approach to working with women who have experienced child sexual abuse. Feminist Review, 68(1), 115-139. https://doi.org/10.1080/01417780110042437.

Weedon, C. (1987). Feminist practice and poststructuralist theory. Oxford: Blackwell.

WHO. (2006). Preventing child maltreatment: A guide to taking action and generating evidence. Geneva: World Health Organization and International Society for Prevention of Child Abuse and Neglect.

Wyatt, G. E., \& Peters, S. D. (1986). Issues in the definition of child sexual abuse in prevalence research. Child Abuse and Neglect, 10(2), 231-240. https://doi.org/10.1016/0145-2134(86)90084-0.

Yuill, R., \& Durber, D. (2008). 'Querying' the limits of queering boys through the contested discourses on sexuality. Sexuality and Culture, 12(4), 257-274. https://doi.org/10.1007/s12119-008-9034-x. 